pointing to a hitherto unknown ritual of canoe-burial. It has been suggested that such canoe-burials may have given rise to the custom of coffin burial, typical in northern England and Denmark. In view of the conservatism characteristic of later maritime forms and custom in Scandinavia, the comparison with the ship-burials of a much later period inevitably is also suggested. These antiquities are on loan to the Museum by Captain A. W. Milburn. The second object of special interest is a stud omamented with millefiori enamel, found at Chesterholme (Vindolanda) in Northumberland in an early fourth century deposit. It has been given by Mr. Eric Birley. It is the only example of millefiori of a late Roman date as yet found in Britain. It is thought that it may, on further study, provide a link with post-Roman Celtic enamels. Bronze objects belonging to the first Babylonian dynasty, circa 2000 B.c., are additions to examples of the art of a period at present poorly represented in the Museum. They are a bronze bar decorated with a ram's head, and three small figures of women. It is probable that they come from sites near the Diyalah River in Iraq.

\section{Meteorological Observation in Certain British Colonies}

IT may be within the recollection of many readers of NATURE that the period August 1, 1932August 31, 1933, was chosen as the Second International Polar Year, during which meteorological observations were to be made at as many places as possible in both arctic and antarctic regions in furtherance of the study of world meteorology. Since the First International Polar Year, fifty years earlier, attention had become directed more to the problem of the exchange of air between equatorial and polar regions, and for that reason corresponding observations were required from middle and lower latitudes. The Governments of several British Colonies have published the special observations made within their areas, and the Meteorological Office, Air Ministry, is supplementing these with the publication of the observations made at a number of places not included in the above-mentioned Colonies, namely, Ascension Island, St. Helena, South Georgia, Falkland Islands, Ocean Island and British Somaliland. These summaries constitute Geophysical Memoir No. 73 of the Meteorological Office (H.M. Stationery Office. 48. 6d. net). Monthly summaries of daily observations of the meteorological quantities most commonly observed are given in tabular form. These are supplemented by hourly readings in a few instances and by records of autographic instruments. The memoir contains no indication of the results of the undertaking as a whole, being only part of the observational material that is becoming available for students of the atmospheric circulation of the globe.

\section{Telephone Circuit Noise Meters}

Mr. H. R. Harbottrle of the Post Office Research Station read a paper on February 4 to the Institution of Electrical Engineers describing an instrument for measuring the disturbing effect of induction from power lines on telephones. During a meeting of the Commission Mixte Internationale held at Dollis Hill, the delegates made comparative measurements of four different types of disturbances by the American, German and valve voltmeter methods. It was agreed that the last-mentioned should be developed and that the precise specification for the actual instrument should be determined by the Comité Consultatif Internationale (the C.C.I. for telephonic communications at great distances). It has been agreed internationally to call an instrument of this type a psophometer. The latest proposals are explained by the author. He states that from comparative measurements of the induction from the Midi Railway, which is supplied with power through mercury arc rectifiers, to the overhead communication lines of the French administration, the results obtained by using the psophometer fully justify this method of making noise measurements. The British Electrical and Allied Industries Research Association has published a pamphlet $M / T 38$ describing the method of constructing a psophometer. About a year ago, a commercial model on similar lines was constructed by the General Electric Co. at Coventry. Others have been made by Siemens and Halske in Germany, by the Administration and Ericssons in Sweden, by Standard Telephones and Cables in England and by the American Telephone and Telegraph Co. At the same meeting, a paper by Dr. A. H. Davis entitled "An Objective Noise Meter for the Measurement of Moderate and Loud, Steady and Impulsive Noises" was also read. The difficulties experienced were surmounted by adopting a technique in which the noise and the reference note are listened to alternately.

\section{Carnegie Trust for the Universities of Scotland}

THE circumstances of the origin of the Trust are recalled in its recently published report for the year 1936-37. Referring to the passing of Lord Craigmyle, formerly one of the trustees, the report quotes a passage from Mr. Carnegie's autobiography which shows that it was an article contributed by the former to the Nineteenth Century magazine in 1897 that led to the idea of a gift of ten million dollars"half of the yearly revenue from it to be used to pay the fees of deserving poor students and the other half to improve the universities". Last year the Trust devoted nearly $£ 52,000$ to the payment of fees of deserving poor students-2,637 men and 897 women. Voluntary refunds of fees advanced by the Trust in previous years, that is, since 1901, amount to nearly $£ 40,000$, namely, $£ 25,000$ by 569 men and $£ 14,500$ by 454 women. Women beneficiaries would seem to be more given to expressing their gratitude in this way than men. Expenditure on post-graduation fellowships, scholarships and grants for research amounted to $£ 17,500$. Resignations of fellows and scholars for the purpose of entering upon professional careers were numerous-a sign, perhaps, of reviving prosperity. This was specially noticeable in the field of chemical research. Of thirty-four fellows and scholars in this field, thirteen were absorbed into industry before the termination of their grants. 